\title{
Moisture Effect on Stiffness of Asphalt Concretes for Low Volume Roads: Comparative Study of Asphalt Institute and Witczak 1-40D Models
}

\author{
Enwuso A. Igwe, Emmanuel O. Ekwulo \& Captain G. Ottos \\ Department of Civil Engineering \\ Rivers State University of Science and Technology, Nkpolu Oroworukwo \\ P.M.B 5080, 5080, Port Harcourt, Rivers State, Nigeria
}

\begin{abstract}
In many parts of the developing nations flexible road constructions are made without due to consideration to drainage facilities due to cost implications and as such most of such pavements fail prematurely. The present study sought to buttress the importance of good drainage facilities as part of avenues to enhance pavement performance and life. The study focused on determining the impact that moisture will develop on pavement stiffness (dynamic modulus) under repeated loads. This involved simulating the effect of moisture on stiffness of flexible pavement using asphalt concretes prepared in the laboratory for low traffic volumes at varying frequencies of loading using Asphalt Institute and Witczak 1-40D Models. The results from the study revealed that flexible pavement when under moisture continuously loses bind-ability between the aggregates and asphalt cement therefore results in stripping of the pavement under repeated traffic loads due to reduction in stiffness (dynamic modulus).
\end{abstract}

\section{INTRODUCTION}

One of the desirable properties of bituminous mixtures is that the resistance to moisture induced damages. The moisture-induced damages (typically known as stripping) can be defined as the weakening or eventual loss of the adhesive bond between the aggregate surface and the asphalt binder in a HMA pavement or mixture, usually under the presence of moisture (Mehari, 2007). The study further stated that the resistance to moisture damage under the presence of moisture in the mixture is a complex matter and the degree mainly depends on the properties of each ingredient materials in the mixture, type and use of mix, environment, traffic, construction practice, and the use of anti-strip additives. Among these factors, aggregate response to asphalt cement under water is primarily responsible for this phenomenon, although some asphalt cement are more subjected to stripping than others.

Road pavements are one of the largest infrastructure components in most of the developed nations of the world (Kim, 2008). For example nations such as France, United Kingdom, Denmark, Italy, Luxembourg, Austria, Ireland, Jordan, Israel, Slovenia and Germany have $100 \%$ completely paved roads as at 2007 (http://www.nationmaster). These facts buttress the need for the science and technology of road pavements. Moreover, without an adequate transport system many economies of the developed nations will be grounded because the movement of goods and services will be scuttled. It is common knowledge to say that nearly every form of transportation system apart from sea transportation will require a road pavement. Thus, the need for proper pavement analysis, evaluation and performance.

Typically flexible pavements are complex in nature such that its composition is multi-layered; consisting of different materials, having various combinations and configurations of frequency of traffic loading that are mostly irregular. Also they are subjected to varying environmental conditions and in particular temperature, moisture and oxidation rates (Robbins, 2009 \& Igwe et al., 2009). Hence, in reality predicting a long-term service life of asphalt pavements is one of the most challenging tasks for pavement engineers in Highway Engineering. However, it is pertinent to say that a common knowledge exist amongst pavement engineers that the performance of flexible pavement is closely related to the performance of asphalt concrete. Thus, many times in pavement engineering flexible pavement performance is constantly being simulated using asphalt (bituminous) concretes. 
In this regard separate studies by Garcia and Thompson (2007) and Robbins (2009) revealed that the most important hot-mix asphalt (HMA) property influencing the structural response of a flexible pavement is the HMA stiffness modulus. Thus, flexible pavement design methods based on elastic theories require that the elastic properties of the pavement materials be known; Brown and Foo (1989). In a previous work by Michael and Ramsis (1988) it was observed that among the common methods of measurement of elastic properties of asphalt mixes (which are Young's, shear, bulk, dynamic complex, double punch, resilient, and Shell Nomograph moduli), the resilient modulus seemed more appropriate for use in multilayer elastic theories. This had been supported by the separate study of Baladi and Harichandran (1988) who posited that resilient modulus measurement by indirect tensile test gives the best result in terms of repeatability.

However this has been contradicted by a more recent research proposed by AASHTO Design Guide 2002 as presented in Clyne et al (2003) which proposes the use of the dynamic modulus ( $\left.E^{*}\right)$ of asphalt mixtures as a parameter in the design procedure; the dynamic modulus emerging as a lead parameter for Simple Performance Test to predict rutting and fatigue cracking in asphalt pavements. Simply defined the dynamic modulus $\left(\mathrm{E}^{*}\right)$ is used to characterize the viscoelastic nature of hot mix asphalt concretes (HMA). It is a measure of the resistance to deformation of HMA concretes under sinusoidal loading. Thus it is the absolute value of the complex modulus consisting of the real part which defines the elastic stiffness and the imaginary which represents the internal damping of the materials (Huang, 1993).

With respect however, to behavioural patterns of asphalt (bituminous) concretes bituminous materials are rheological by nature meaning that their stress-strain relationship is both time and temperature dependent (Suhaibani, 1995). Such relationship is referred to as the stiffness of mix, which at rapid rates of loading, such as moving traffic and low temperatures tends towards elastic modulus. On the other hand at long loading duration and high temperature the behaviour of the concrete becomes viscous and visco-elastic at intermediate conditions (Bolk, 1981 \& Pell, 1987) in previous studies.

Also in a previous study to Suhaibani, Tayebali et al., (1994) revealed that stiffness of asphaltaggregate mixes is of paramount importance in determining how well a pavement performs and is fundamental to the analysis of pavement response to traffic loading. Their findings further revealed that all stiffness test systems that were investigated were found to be responsive to mix behaviour and test variables such as asphalt type, asphalt content, aggregate type, and amount of air-voids and temperature. The results showed that each of these variables had either a direct effect on stiffness or an indirect effect through interactions with other variables and temperature having by far the most influence on axial, diametral, and flexural stiffnesses.

In the light of the present study stiffness of asphalt concretes simply refers to the relationship between the stresses and strains within the asphalt concrete under various external conditions of disturbance. Robbins (2009) argued that 3 fundamental parameters affect stress-strain behaviour of asphalt concrete - traffic (loading and configuration), climate (moisture and temperature) and material properties of the concrete. It can therefore be concluded that these same parameters affect stiffness of asphalt concrete. According to Diefenderfer, et al., (2002) in a previous study they concluded that there are at least six negative effects related to excess water (moisture) on pavement properties. The study revealed that reduction of shear strength of unbound materials, differential swelling on expansive sub grade soils, movement of unbound fines in flexible pavement base and sub base layers, pumping of fines and durability cracking in rigid pavements, frost-heave and thaw weakening, and stripping of asphalt in flexible pavements are some of the negative effects of increase moisture. A recent study also revealed that one of the major contributors to pavement failure is moisture when allowed to settle longer that should be on the pavement (Magdi, 2014).

On this basis the major consideration of the present study was premised on the damage that moisture can cause on a flexible pavement with respect to its stiffness and in particular dynamic modulus (which can be determined directly in the laboratory or by use of predictive models) when under submergence at varying times in days. However, laboratory simulation using asphalt concrete which is synonymously used to represent flexible pavement was analyzed under varying frequencies of loading at different soaking conditions of moisture between 0-5 days for a low volume road pavement (i.e. ESAL $\leq 500,000)$ to ascertain the effects of moisture on dynamic modulus. The study involved a comparative analysis using the Asphalt Institute (1993) model for determining dynamic modulus and the Witczak 1-40D (Bari and Witczak, 2006) model for determining dynamic modulus. The research 
objectives to the study are therefore as follow; (a) ascertain changes in dynamic modulus of asphalt pavement using asphalt concretes with respect to moisture submergence between 1-5 days for traffic loading frequencies of 1, 5 and $10 \mathrm{~Hz}$ respectively using Asphalt Institute and Witczak 1-40D models; (b) ascertain similarities in change pattern using both models; (c) establish a relationship between Asphalt Institute dynamic modulus and Witczak 1-40D dynamic modulus under same conditions of soaking in moisture for the traffic frequencies aforesaid.

\section{MAterials AND Methods}

\subsection{Sampling of Materials used}

Materials used for the preparation of the asphalt concrete samples in order to simulate actual flexible pavement behaviour under investigation were collected from different sources. The asphalt cement or bitumen used was obtained from Setraco; a Construction Company in Port Harcourt City in Rivers State, Nigeria. On the other hand the aggregates (gravel and sand) used were obtained directly from market dealers at Mile 3 Diobu Port Harcourt, Rivers State, Nigeria.

\subsection{Classification Tests}

The method to achieving the purpose of the present study involved first classification of the materials used - asphalt cement and aggregates. That is, the specific gravity of both the asphalt cement and aggregates were determined as presented in section 3. Also classification test of bitumen was done to determine penetration, viscosity and softening point of the bitumen used -See section 3 for results.

\subsection{Sample Preparation}

The asphalt concrete samples used for simulation were prepared in accordance with the guidelines as stated by Bruce Marshal for Mix Design Procedures as presented in (Chapius, Kim, Shamour and Shuler -1992) and Roberts et al., (1996).

The procedure involved the preparation of a series of test specimens for a range of asphalt (bitumen) contents such that test data curves showed well defined optimum values. Tests were scheduled on the bases of 0.5 percent increments of asphalt content with at least 2 -asphalt contents above and below the optimum asphalt content. In order to provide adequate data, three replicate test specimens were prepared for each set of asphalt content used. During the preparation of the asphalt concrete samples, the aggregates were first heated for about 5 minutes before asphalt (bitumen) was added to allow for absorption into the aggregates. After which the mix was poured into a mould and compacted on both faces with 25 blows (indicating light traffic case or low volume road) using a $6.5 \mathrm{~kg}$-rammer freely falling from a height of $450 \mathrm{~mm}$. Compacted specimens were subjected to bulk specific gravity test (ASTM D2727), stability and flow, density and voids analyses at a temperature of $60^{\circ} \mathrm{C}$ and frequencies of 1,5 , and $10 \mathrm{~Hz}$ respectively as specified by AASHTO Design Guide (2002). The results obtained were used to determine the optimum asphalt content of the asphalt concrete. Also results from air voids variation together with other properties of both the aggregates and asphalt (bitumen) were used to compute dynamic modulus using Asphalt Institute model and Witczak 1-40D model.

\subsection{Model Equations adopted for comparison}

The Asphalt Institute (1993) and Witczak 1-40D (Bari and Witczak, 2006) model equations for computing dynamic modulus adopted for comparative analysis is as presented in Equations $1-7 \& 8$ respectively;

\section{Asphalt Institute Model}

$$
\begin{aligned}
& \mathrm{E}^{*}=100,000\left(10^{\beta}{ }_{1}\right) \\
& \beta_{1}=\beta_{3}+0.000005 \beta_{2}-0.00189 \beta_{2} f^{-1.1} \\
& \beta_{2}=\beta_{4}{ }^{0.5} T^{\beta_{5}} \\
& \beta_{3}=0.553833+0.028829\left(P_{200} f^{-0.1703}\right)-0.03476 V_{a}+0.07037 \lambda+0.931757 f^{-0.02774} \\
& \beta_{4}=0.483 V_{b}
\end{aligned}
$$


Enwuso A. Igwe et al.

$\beta_{5}=1.3+0.49825 \log f$

$\lambda=29,508.2\left(\mathrm{P}_{77^{\circ} \mathrm{F}}\right)^{-2.1939}$

Where;

$\mathrm{E}^{*}=$ dynamic modulus (psi)

$\mathrm{F}=$ loading frequency $(\mathrm{Hz})$

$\mathrm{T}=$ temperature $\left({ }^{\circ} \mathrm{F}\right)$

$\mathrm{V}_{\mathrm{a}}=$ volume of air voids $(\%)$

$\lambda=$ asphalt viscosity at $77^{\circ} \mathrm{F}$ or use equation $7\left(10^{6}\right.$ poise $)$

$\mathrm{P}_{200}=$ percentage by weight of aggregates passing No. $200(\%)$

$\mathrm{V}_{\mathrm{b}}=$ volume of bitumen

$\mathrm{P}_{77^{\circ} \mathrm{F}}=$ penetration at $77^{\circ} \mathrm{F}$ or $25^{\circ} \mathrm{C}$

\section{Witczak Model}

$$
\begin{aligned}
& \log E^{*}=-1.249937+0.029232 P_{200}-0.001767\left(P_{200}\right)^{2}+0.002841 P_{4}-0.05809 V_{a}-\frac{0.802208 V_{b e f f}}{\left(V_{b e f f}+V_{a}\right)} \\
& \frac{3.871977-0.0021 P_{4}+0.003958 P_{38}-0.000017\left(P_{38}\right)^{2}+0.00547 P_{34}}{1+e^{(-0.603313-0.31335 \log f-0.393532 \log \eta)}}
\end{aligned}
$$

Where,

$\left|\mathrm{E}^{*}\right|=$ asphalt mix complex modulus, in $10^{5} \mathrm{psi}$;

$\eta=$ bitumen viscosity, in $10^{6}$ poise;

$f=$ load frequency, in $\mathrm{Hz}$;

$\mathrm{V}_{\mathrm{a}}=$ percent air voids in the mix, by volume;

$\mathrm{V}_{\text {beff }}=$ percent effective bitumen content, by volume;

$\mathrm{P}_{34}=$ percent retained on 3/4-in. sieve, by total aggregate weight

$\mathrm{P}_{38}=$ percent retained on 3/8-in. sieve, by total aggregate weight

$\mathrm{P}_{4}=$ percent retained on No. 4 sieve, by total aggregate weight

$\mathrm{P}_{200}=$ percent passing No. 200 sieve, by total aggregate weight

\section{Results (See Tables 1 - 5 \& Figures 1 - 2)}

Table1. Classification Test Results of Materials used

\begin{tabular}{|l|l|l|l|l|}
\hline Material & & Asphalt & Sand & Gravel \\
\hline Specific gravity & & 1.06 & 2.60 & 2.82 \\
\hline Grade of binder material & - & $40 / 50$ & - & - \\
\hline Mix proportion (\%) & - & - & 42 & 58 \\
Viscosity of binder (poise) & - & $5.7 *\left(10^{-4}\right)$ & - & - \\
Softening point & - & & - & - \\
Penetration value & - & $41.5^{\circ} \mathrm{C}$ & - & - \\
& & $51.3 \mathrm{~mm}$ & & \\
\hline
\end{tabular}

Table2. Schedule of Aggregates Used For Mix Proportion in Accordance With ASTM 1951: C136

\begin{tabular}{|l|l|l|l|l|}
\hline $\begin{array}{l}\text { Sieve size } \\
(\mathbf{m m})\end{array}$ & $\begin{array}{l}\text { Specification } \\
\text { limit }\end{array}$ & $\begin{array}{l}\text { Aggregate A } \\
\text { (Gravel) }\end{array}$ & $\begin{array}{l}\text { Aggregate B } \\
\text { (Sand) }\end{array}$ & $\begin{array}{l}\text { Mix proportion } \\
(\mathbf{0 . 5 8 A + 0 . 4 2 B})\end{array}$ \\
\hline 19.0 & 100 & 100 & 100 & 100 \\
\hline 12.5 & $86-100$ & 99.27 & 100 & 99.58 \\
\hline 9.5 & $70-90$ & 53.45 & 100 & 73.00 \\
\hline
\end{tabular}


Moisture Effect on Stiffness of Asphalt Concretes for Low Volume Roads: Comparative Study of Asphalt Institute and Witczak 1-40D Models

\begin{tabular}{|l|l|l|l|l|}
\hline \hline 6.3 & $45-70$ & 26.69 & 100 & 57.48 \\
\hline 4.75 & $40-60$ & 13.56 & 98.88 & 49.18 \\
\hline 2.36 & $30-52$ & 5.90 & 92.56 & 42.30 \\
\hline 1.18 & $22-40$ & 3.77 & 79.12 & 35.42 \\
\hline 0.6 & $16-30$ & 2.65 & 43.70 & 19.89 \\
\hline 0.3 & $9-19$ & 1.85 & 10.84 & 5.63 \\
\hline 0.15 & $3-7$ & 0.40 & 0.02 & 0.24 \\
\hline 0.075 & 0 & 0.11 & 0 & 0.06 \\
\hline PAN & 0 & 0.01 & 0 & 0 \\
\hline
\end{tabular}

Table3. Asphalt Concrete Properties under varying Moisture Conditions of Soaking

\begin{tabular}{|l|l|l|l|l|l|}
\hline $\begin{array}{l}\text { Soaking in Moisture Condition } \\
\text { (Days) }\end{array}$ & $\begin{array}{l}\text { Stability } \\
(\mathrm{N})\end{array}$ & $\begin{array}{l}\text { Flow } \\
(0.25 \mathrm{~mm})\end{array}$ & $\begin{array}{l}\text { Density } \\
\left(\mathrm{kg} / \mathrm{m}^{3}\right)\end{array}$ & $\begin{array}{l}\text { Air Voids } \\
(\%)\end{array}$ & $\begin{array}{l}\text { VMA } \\
(\%)\end{array}$ \\
\hline 0 & 6160 & 8.3 & 2251 & 5.31 & 19.45 \\
\hline 1 & 5880 & 8.4 & 2250 & 5.34 & 19.49 \\
\hline 2 & 5600 & 8.5 & 2240 & 5.59 & 19.85 \\
\hline 3 & 4370 & 8.6 & 2230 & 5.84 & 20.21 \\
\hline 4 & 4030 & 8.9 & 2210 & 6.35 & 20.92 \\
\hline 5 & 3600 & 9.1 & 2207 & 6.43 & 21.03 \\
\hline
\end{tabular}

Table4. Variation of Dynamic Modulus (MPa) with Days of Soaking in Moisture

\begin{tabular}{|l|l|l|l|l|l|l|}
\hline $\begin{array}{l}\text { Days of Soaking } \\
\text { in Moisture }\end{array}$ & \multicolumn{5}{l}{ Frequency of traffic loading (Hz) } & F = 10Hz \\
\hline & F = 1Hz & F = 5Hz & Witczak \\
\hline & $\begin{array}{l}\text { Asphalt } \\
\text { Institute }\end{array}$ & Witczak & $\begin{array}{l}\text { Asphalt } \\
\text { Institute }\end{array}$ & Witczak & Asphalt Institute & \\
\hline 0 & 822.89 & 320.46 & 1127.81 & 521.06 & $1,305.80$ & 647.63 \\
\hline 1 & 820.92 & 320.01 & $1,125.11$ & 520.33 & $1,302.67$ & 646.71 \\
\hline 2 & 804.66 & 316.09 & $1,102.82$ & 513.95 & $1,276.86$ & 638.79 \\
\hline 3 & 788.72 & 311.92 & $1,080.98$ & 507.17 & $1,251.56$ & 630.35 \\
\hline 4 & 757.17 & 302.75 & $1,037.74$ & 492.27 & $1,201.50$ & 611.83 \\
\hline 5 & 752.33 & 301.25 & $1,031.16$ & 489.82 & $1,193.84$ & 608.79 \\
\hline Rate of change & -0.08575 & -0.05995 & -0.08570 & -0.05995 & -0.08574 & -0.05997 \\
\hline
\end{tabular}

Table5. Correlation of Asphalt Institute dynamic Modulus with Witczak 1-40D dynamic Modulus

\begin{tabular}{|c|c|c|c|c|c|c|c|c|c|}
\hline \multirow{3}{*}{$\begin{array}{l}\text { Days of } \\
\text { Soaking in } \\
\text { Moisture }\end{array}$} & \multicolumn{9}{|c|}{ Frequency of traffic loading $(\mathrm{Hz})$} \\
\hline & \multicolumn{2}{|l|}{$\mathrm{F}=1 \mathrm{~Hz}$} & \multirow[b]{2}{*}{$\begin{array}{l}\mathrm{E}^{*}{ }_{\mathrm{AI}} / \mathrm{E}^{*} \\
\text { WIT }\end{array}$} & \multicolumn{2}{|l|}{$\mathrm{F}=5 \mathrm{~Hz}$} & \multirow[b]{2}{*}{$\begin{array}{l}\mathrm{E}^{*}{ }_{\mathrm{AI}} / \mathrm{E}^{*} \\
\text { WIT }\end{array}$} & \multicolumn{2}{|l|}{$\mathrm{F}=10 \mathrm{~Hz}$} & \multirow[b]{2}{*}{$\begin{array}{l}\mathrm{E}^{*}{ }_{\mathrm{AI}} / \mathrm{E} \\
*_{\mathrm{WIT}}\end{array}$} \\
\hline & $\begin{array}{l}\text { Asphalt } \\
\text { Institute }\end{array}$ & Witczak & & $\begin{array}{l}\text { Asphalt } \\
\text { Institute }\end{array}$ & Witczak & & $\begin{array}{l}\text { Asphalt } \\
\text { Institute }\end{array}$ & Witczak & \\
\hline 0 & 822.89 & 320.46 & 2.57 & 1127.81 & 521.06 & 2.16 & $1,305.80$ & 647.63 & 2.02 \\
\hline 1 & 820.92 & 320.01 & 2.57 & $1,125.11$ & 520.33 & 2.16 & $1,302.67$ & 646.71 & 2.01 \\
\hline 2 & 804.66 & 316.09 & 2.55 & $1,102.82$ & 513.95 & 2.15 & $1,276.86$ & 638.79 & 2.00 \\
\hline 3 & 788.72 & 311.92 & 2.53 & $1,080.98$ & 507.17 & 2.13 & $1,251.56$ & 630.35 & 2.00 \\
\hline 4 & 757.17 & 302.75 & 2.50 & $1,037.74$ & 492.27 & 2.11 & $1,201.50$ & 611.83 & 2.00 \\
\hline 5 & 752.33 & 301.25 & 2.50 & $1,031.16$ & 489.82 & 2.11 & $1,193.84$ & 608.79 & 2.00 \\
\hline Average Rate & & & 2.54 & & & 2.14 & & & 2.01 \\
\hline
\end{tabular}

Where $E^{*}{ }_{A I}=$ Asphalt Institute dynamic modulus; $E^{*}{ }_{\text {WIT }}=$ Witczak 1-40D dynamic modulus 


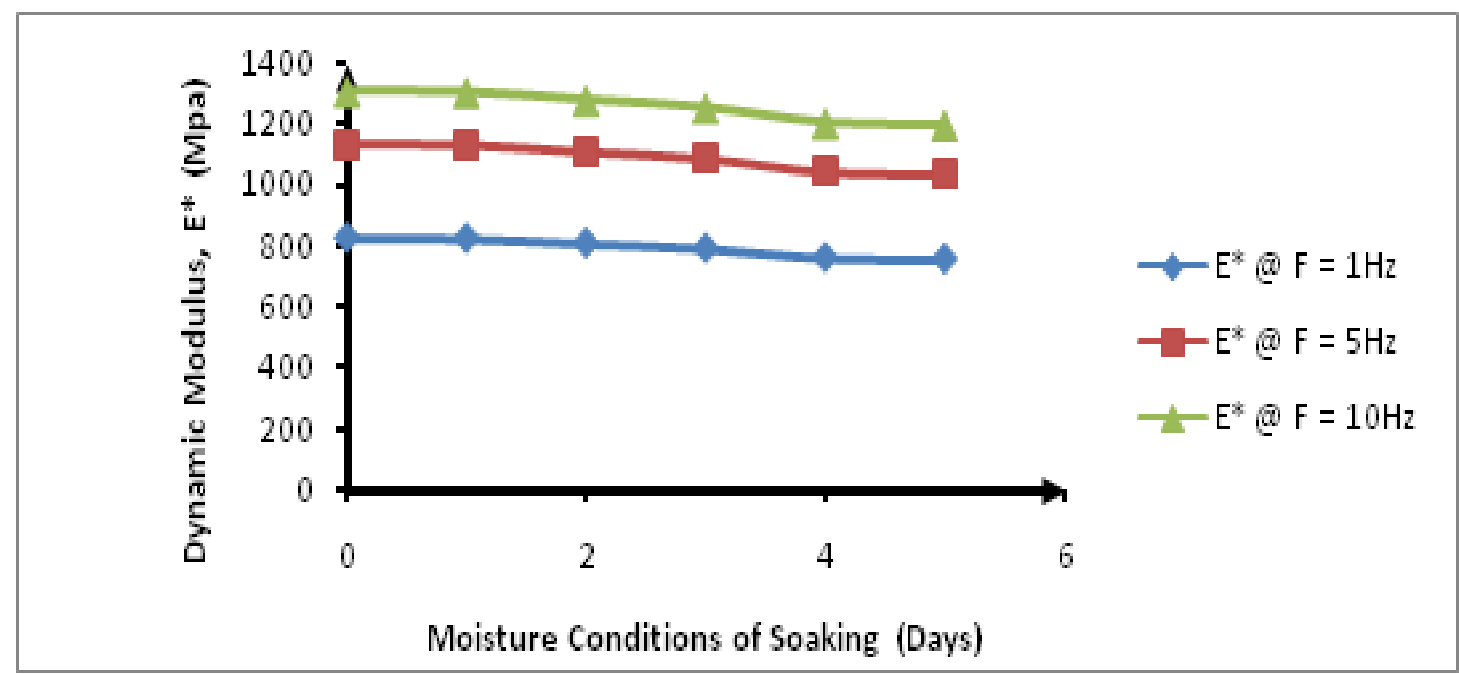

Figure1. Asphalt Institute Dynamic Modulus variation with Moisture

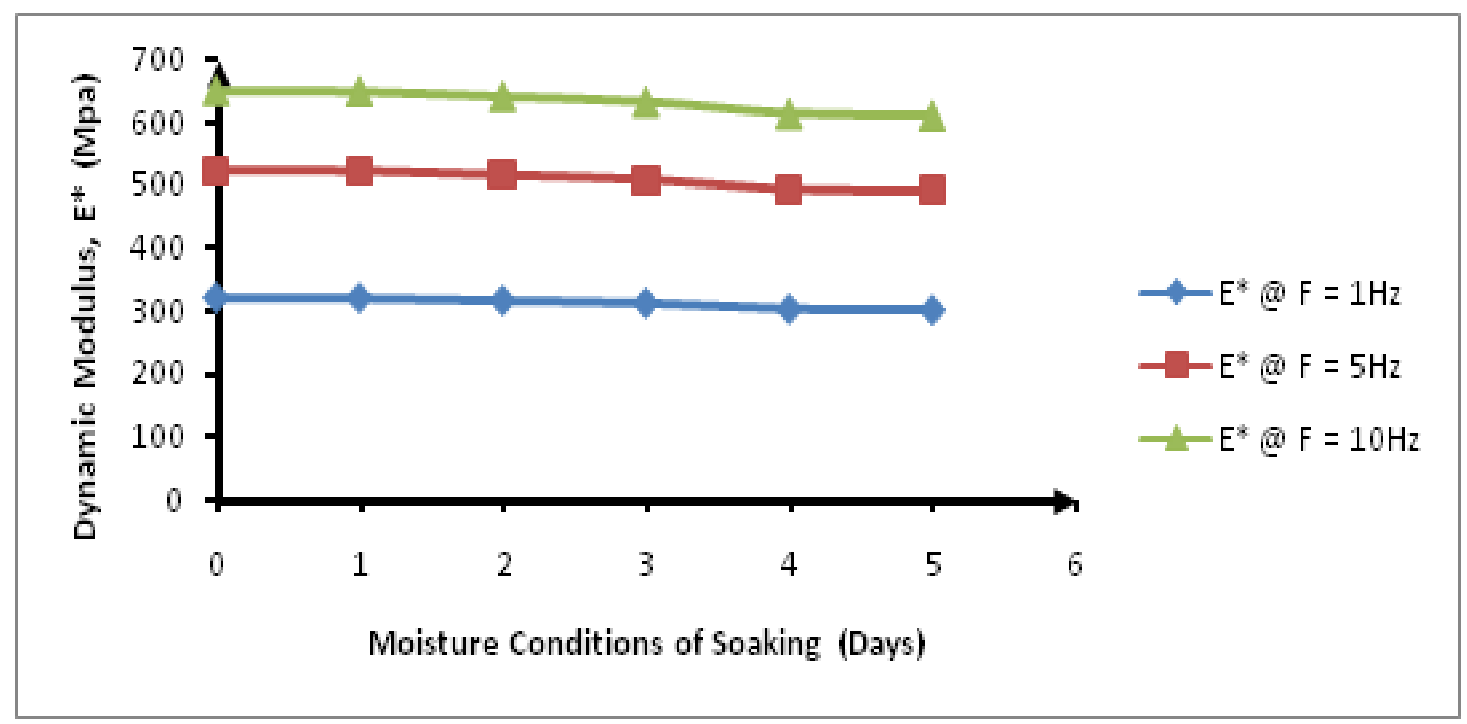

Figure2. Witczak 1-40D Dynamic Modulus variation with Moisture

\section{DisCUSSIONS}

\subsection{Changes in Dynamic Modulus}

From Figure 1, the results obtained using Asphalt Institute Model revealed that stiffness (dynamic modulus) of the asphalt concretes reduced constantly with respect to moisture variation from Day 0 Day 5 for all frequencies of traffic loading (See Table 4 above).

Similarly, from Figure 2, the results obtained using Witczak 1-40D Model revealed that stiffness (dynamic modulus) of the asphalt concretes reduced constantly with respect to moisture variation from Day 0 - Day 5 for all frequencies of traffic loading (See Table 4 above).

The implication of both results shows that flexible pavements when exposed to moisture submergence will suffer "continuous stripping" as long as they remain under moisture. The reason is because moisture percolation into the pavement pores creates increased air voids and mineral volume such that the binding relationship between asphalt cement and the aggregates in the pavement is grossly reduced and as such creates separation or in proper terms STRIPPING (Mehari, 2007). This suggests that at a time $\mathrm{t}=\infty$ days; there is likely to be absolute separation since there may exist no binding between asphalt cement and aggregates.

\subsection{Similarities in Patterns of Change for both Models}

From Table 4, results obtained using Asphalt Institute Model revealed that the average rate of change of stiffness (dynamic modulus) with respect to moisture variation was the same irrespective of the frequency of traffic loading with an average of $(-8.6 \%)$ or -0.086 . 
Similarly, From Table 4, results obtained using Witczak 1-40D Model revealed that the average rate of change of stiffness (dynamic modulus) with respect to moisture variation was the same irrespective of the frequency of traffic loading with an average of $(-6 \%)$ or -0.06 .

In summary, $\mathrm{E}^{*}{ }_{\mathrm{AI}}$ had a higher rate of stripping than $\mathrm{E}^{*}{ }_{\mathrm{WIT}}$.

\subsection{Relationship between Models}

From Table 5, it was observed that the higher the frequency of traffic loading the closer the dynamic modulus $\left(\mathrm{E}^{*}\right)$ of both models. For instance at a traffic loading frequency of $1 \mathrm{~Hz} ; \mathrm{E}^{*}{ }_{\mathrm{AI}} \approx 2.54 \mathrm{E}^{*}{ }_{\mathrm{WIT}}$ at any time $\mathrm{t}=0-5$ days. Similarly, at traffic loading frequency of $5 \mathrm{~Hz}$ and $10 \mathrm{~Hz} ; \mathrm{E}^{*}{ }_{\mathrm{AI}} \approx 2.14 \mathrm{E}^{*}{ }_{\mathrm{WIT}}$ and $\mathrm{E}^{*}{ }_{\mathrm{AI}} \approx 2.01 \mathrm{E}^{*}{ }_{\mathrm{WIT}}$ at any time $\mathrm{t}=0-5$ days repectively.

The results suggests that the longer the pavement stays in moisture at a time $t=\infty$ days and higher frequency of traffic loading $\mathrm{E}^{*}{ }_{\mathrm{AI}} \approx \mathrm{E}^{*}{ }_{\mathrm{WIT}}$ because at this point there will be absolute stripping of aggregates from the asphalt cement hence stiffness aproaches zero in either condition.

\section{Conclusions}

From the results obtained and observations made the following conclusions are drawn;

- That moisture has significant negative impact on stiffness (dynamic modulus) of asphalt concretes and by extension on flexible pavement when submerged in moisture.

- That the negative impact of moisture on asphalt concretes results in stripping between the aggregates and asphalt cement thus can cause premature pavement failure when allowed continuously under moisture.

- That drainage conditions become pertinent in order to remove stripping effect of moisture on pavement for longer service life.

\section{REFERENCES}

[1] AASHTO Design Guide Draft (2002) - 2.4 Modulus of Elasticity for Major Material Groups, NCHRP Project 1-37A.

[2] Asphalt Institute (1993) "Mix Design Methods for Asphalt Concrete and other Hot Mix Types", MS-2, Sixth Edition.

[3] Baladi, G. Y. and Harichandran S. R, (1988) 'Asphalt Mix Design and the IndirectTest':A New Horizon.

[4] Bari, J. and Witczak, M. W. (2006) "Development of a New Revised Version of the Witczak E* Predictive Model of Hot Mix Asphalt Mixtures", Journal of the Association of Asphalt Paving Technologist, 75,381-424.

[5] Bolk, H. J. N. A., (1981) "The Creep Test", Study Center for Road Construction, Amhem, The Netherlands, S. C. W., record 5.

[6] Brown, E. R. and Foo, K. Y. (1989) 'Evaluation of Variability in Resilient ModulusTest results'(ASTM D 41 23) National Centre for Asphalt Technology: Report No. 91-6.

[7] Chapuis, R.P. and Legare, P. P., (1992) "A Simple Method for Determining the Surface Area of Fine Aggregates and Fillers in Bituminous Mixtures," Effect of Aggregates and Mineral Fillers On asphalt Mixtures Performance, ASTM STP 1147, Richard C. Meininger, Ed., American Society for Testing and Material, Philadelphia.

[8] Clyne, T. R.; Li, X.; Marasteanu, M. O.; and Skok, E. L. (2003) 'Dynamic and Resilient Modulus of Mn/DOT Asphalt Mixtures' Final Report, University of Minnesota, Department of Civil Engineering: published by Minnesota Department of Transportation Research Services.

[9] Garcia, G., and Thompson M. R., (2007) "HMA Dynamic Modulus Predictive Models: A Review", Report of the Findings of ICt-R39: Validation of Extended Life HMA design Concepts, Research Report FHWA-ICT-07-005.

[10] Huang, Y.H. Pavement Analysis and Design. 1st Ed., Prentice Hall, Upper River Saddle, N.J., 1993.

[11] Igwe, E. A.; Ayotamuno, M. J.; Okparanma, R. N.; Ogaji, S. O. T.; and Probert,S. D. (2009) 'Road Surface Properties affecting Rates of Energy Dissipation from Vehicles' Journal of Applied Energy, vol. 86, pp. 1692-1696, Elsevier Publishing. 
[12] Kim, Y. R. (2008) "Modeling of Asphalt Concrete", Chapter 1.

[13] Kim, Y. R., Kim, N., and Khosla, N. P.,(1992) "Effects of Aggregate Type and Gradation on Fatigue and Permanent Deformation of Asphalt Concrete," Effect of Aggregates and Mineral Fillers On asphalt Mixtures Performance, ASTM STP 1147, Richard C. Meininger,Ed., American Society for Testing and Material, Philadelphia.

[14] Mehari, Z. B. (2007) "Effect of Different Types of Filler Materials on Characteristics of HotMix-Asphalt Concrete", A thesis submitted to School of Graduate Studies of Addis Ababa University in partial fulfillment of the requirements for the degree of Master of Science in Civil Engineering (Road and Transport Engineering)

[15] Michael, M. S. and Ramsis, S. T. (1988) 'The Modulus of Asphalt Mixtures - An Unresolved Dilemma' Transportation Research Board, 67th annual meeting.

[16] NationMaster@http://www.nationmaster.com/country- info/stats/Transport/Roads/Paved/\%of-total-roads: accessed online on July 19, 2016.

[17] Pell, P. S. (1987) "keynote Address-Pavement Materials", $6^{\text {th }}$ International Conference on the Structural Design of Asphalt Pavements, The Uninersity of Mich, Proc., Vol. 2, pp. 36-70.

[18] Robbins, M. M. (2009) "An investigation into dynamic complex modulus of Hot Mix Asphalt an it's contributing factor" Thesis presented to the Department of Civil Engineering, University of Toledo, USA, MSc Civil Engineering, Directed by David H. Timm.

[19] Sharrour, A. M., and Saloukeh, G.B., (1992) "Effect of Quality and Quantity of Locally Produced Filler (Passing Sieve No. 200) on Asphaltic Mixtures in Dubai”, Effect of Aggregates and Mineral Fillers On asphalt Mixtures Performance, ASTM STP 1147, Richard C. Meininger, Ed., American Society for Testing and Material, Philadelphia.

[20] Shuler, T. S., and Huber, G. A., (1992) "Effect of Aggregate Size and Other Factors on Refusal Density of asphalt Concrete by Vibratory Compaction", Effect of Aggregates and Mineral Fillers On asphalt Mixtures Performance, ASTM STP 1147, Richard C. Meininger,Ed., American Society for Testing and Material, Philadelphia.

[21] Suhaibani, A. A., Sharaf, E. A., and Al-Abdulatif, A., (1995) "A Calibrated Prediction Model for Asphalt Concrete Modulus Based on Local Conditions - The Fourth Saudi Engineering Conference, Vol. 2.

[22] Tayebali, A. A., Tsai, B., and Monismith, C. L. (1994) "Iinstitute of Transportation Studies, University of California, Berkeley, National Research Council Program, Washington. 